\title{
PENGGUNAAN MODEL PEMBELAJARAN JIGSAW UNTUK PENINGKATAN DAYA TARIK BELAJAR SISWA PADA PELAJARAN PENDIDIKAN AGAMA KELAS IV 064012 KEC MEDAN PETISAH
}

\author{
Purnama Purba ${ }^{1}$ \\ Surel: purnamapurba@gmail.com
}

\begin{abstract}
The purpose of this study was to increase the learning attractiveness of students through the jigsaw type learning model in class IV 060412 Medan Denai religious studies. The data analysis technique used is an interactive analysis technique developed by Miles and Huberman. Interactive analysis consists of 4 components of activities that are interrelated with each other which includes data reduction, display (data), and drawing conclusions.
\end{abstract}

\section{Keywords: Jigsaw Model, Attraction}

\begin{abstract}
ABSTRAK
Tujuan penelitian ini adalah untuk peningkatan daya tarik belajar siswa melalui model pembelajaran tipe jigsaw pada pelajaran agama kelas IV 060412 Medan Denai. Teknik analisa data yang digunakan adalah teknik analisa interaktif yang dikembangkan oleh Miles dan Huberman. Analisa interaktif tersebut terdiri atas 4 komponen kegiatan yang saling terkait satu sama lain yang meliputi reduksi data, beberan (display) data, dan penarikan kesimpulan.
\end{abstract}

Kata Kunci : Model Jigsaw, Daya Tarik

PENDAHULUAN

Pendidikan Agama Kristen adalah usaha yang dilakukan secara terencana dan berkesinambungan dalam rangka mengembangkan kemampuan peserta didik untuk memperteguh iman dan ketaqwaan terhadap Tuhan Yang Maha Esa sesuai dengan ajaran Gereja dengan tetap memperhatikan penghormatan terhadap agama lain dalam hubungan kerukunan antarumat beragama dalam masyarakat untuk mewujudkan persatuan nasional.
Sedangkan pendidikan berfungsi membantu peserta didik dalam pengembangan dirinya, yaitu pengembangan semua potensi, kecakapan, serta karakteristik pribadinya kearah yang positif, baik bagi dirinya maupun lingkungannya. Pendidikan bukan sekedar memberikan pengetahuan atau nilainilai atau melatih ketrampilan. Pendidikan berfungsi mengembangkan apa yang secara potensial dan aktual telah dimiliki peserta didik. 
Dalam proses pembelajaran diharapkan antara guru, siswa dan lingkungan belajar saling mendukung sehingga akan tercapai tujuan pembelajaran yaitu perubahan perilaku dan tingkah laku yang positif dari peserta didik setelah mengikuti kegiatan belajar mengajar, seperti perubahan yang secara psikologis akan tampil dalam tingkah laku yang dapat diamati melalui alat indera oleh orang lain baik tutur katanya, motorik dan gaya hidupnya.

Kurangnya daya tarik belajar siswa serta masih adanya beberapa siswa yang kurang fokus dalam mengikuti pelajaran agama masih dijumpai di Kelas IV 064012 Kec. Medan Petisah. Hal ini terjadi karena kurangnya kreatif guru dalam mengajar dan minimnya metode yang digunakan sehingga membuat siswa belajar agama hanya sebagai rutinitas yang diharuskan untuk dipelajari oleh seluruh siswa yang beragama Kristen.

kelompok kecil yang heterogen untuk bekerja sama dan saling membantu untuk mencapai tujuan, tujuan dalam pembelajaran kooperatif adalah pencapaian daya tarik belajar siswa meningkat.

Pembelajaran kooperatif dapat digunakan dalam berbagai mata pelajaran dari segala usia. Penggunaan model-model pembelajaran jigsaw I, II, dan III secara simultan di dalam proses belajar Pendidikan Agama Kristen mampu meningkatkan daya tarik
Berdasarkan survei yang saya lihat, daya tarik belajar siswa dalam mengikuti pelajaran Pendidikan Agama Kristen sangat rendah. Siswa Kelas IV 064012 Kec Medan Petisah kurang merespon, kurang berminat pelajaran yang disampaikan oleh guru agama. Karena guru agama masih menggunakan model

pembelajaran ceramah yang membuat siswa bosan dan jenuh dalam mengikuti pelajaran Pendidikan Agama Kristen.

Tujuan pembelajaran dikatakan berhasil apabila siswa telah memiliki kemampuan untuk menguasai materi yang telah ditetapkan dalam kurikulum.

Salah satu model pembelajaran yang akan digunakan oleh guru agama Katolik ialah dengan menggunakan model pembelajaran "Cooperative Learning". Model pembelajaran Cooperative Learning adalah suatu model pembelajaran yang berpusat pada penerapan belajar siswa. Pada dasarnya, setiap mata pelajaran memiliki daya tarik tersendiri, meskipun daya tarik ini amat tergantung pada karakteristik siswa, seperti: bakat, kebutuhan, minat, serta kecenderungankecenderungan atau pilihan-pilihan per-seorangan lainnya. Suatu mata pelajaran memiliki daya tarik tinggi bisa karena sesuai dengan bakat siswa, atau dibutuhkan secara pribadi oleh siswa, atau karena sekedar minat. Daya tarik inilah yang 
Purnama Purba: Penggunaan Model-Model..

menyebabkan siswa ingin mempelajari mata pelajaran itu.

Namun kecenderungan ini, bagaimanapun juga, dipengaruhi oleh bagaimana mata pelajaran itu diorganisasi dan disampaikan kepada siswa. Jadi, strategi pengorganisasian pembelajaran dan penyampaian pembelajaran memegang peranan yang amat penting untuk mempertahankan dan sekaligus menunjukkan daya tarik mata pelajaran. Meskipun demikian, strategi pengelolaan, yang berfungsi untuk menata penggunaan kedua strategi pembelajaran itu, peranannya tak dapat diabaikan.

\section{METODE PENELITIAN}

Tujuan penelitian ini adalah untuk peningkatan daya tarik belajar siswa melalui model pembelajaran tipe jigsaw pada pelajaran agama kelas IV 060412 Medan Denai.

Tempat penelitian ini dilaksanakan oleh peneliti di SD Negeri 064012 Medan Petisah. Adapun alasan penulis memilih sekolah ini sebagai tempat penelitian adalah untuk mengembangkan dan menciptakan pembelajaran yang efektif dan efisien di lingkungan sekolah dengan menggunakan model pembelajaran kooperatif tipe jigsaw I, II, dan III.

\section{HASIL DAN PEMBAHASAN Pertemuan I}

Hasil penelitian Pertemuan I menyajikan laporan hasil-hasil setiap
Teknik analisa data yang digunakan adalah teknik analisa interaktif yang dikembangkan oleh Miles dan Huberman. Analisa interaktif tersebut terdiri atas 4 komponen kegiatan yang saling terkait satu sama lain yang meliputi reduksi data, beberan (display) data, dan penarikan kesimpulan.

Tabel.2.1

Frekuensi Tingkat Keaktifan Siswa Pertemuan I

\begin{tabular}{|l|l|l|l|}
\hline & & Persent & Tingka \\
\hline Kateg & Frekue & ase & $\mathrm{t}$ \\
\hline ori & nsi & Frekue & Keakti \\
\hline & & nsi & fan \\
\hline $90 \%-$ & 4 & $20 \%$ & Sangat \\
\hline $100 \%$ & & & Aktif \\
\hline $75 \%$ & 6 & $30 \%$ & Aktif \\
\hline- & & & \\
\hline $89 \%$ & & & \\
\hline $55 \%-$ & 7 & $35 \%$ & Kuran \\
\hline $74 \%$ & & & g \\
\hline & & & Aktif \\
\hline $35 \%-$ & 3 & $15 \%$ & Tidak \\
\hline $54 \%$ & & & Aktif \\
\hline $0 \%-$ & 0 & $\%$ & Sangat \\
\hline $34 \%$ & & & Tidak \\
\hline & & & Aktif \\
\hline
\end{tabular}

tahapan penelitian tindakan kelas, mulai perencanan, pelaksanaan tindakan, observasi dan evaluasi, dan refleksi. Berdasarkan hasil tindakan I, faktor yang diduga menjadi 
penyebab timbulnya permasalahan tersebut adalah metode yang dipakai kurang bisa membantu siswa untuk menuangkan idenya karena siswa baru mengenal metode pembelajaran jigsaw I.

Kegiatan

pengamatan

Pertemuan I ini dilakukan untuk

\section{Pertemuan II}

\section{a. Perencanaan}

Berdasarkan hasil yang dicapai pada pertemuan I maka rencana tindakan kelas siklus II perlu direvisi yang hasilnya akan digunakan sebagai acuan pelaksanaan tindakan kelas siklus III.

\section{b. Pelaksanaan}

Pelaksanaan pada pertemuan II ini sama dengan tindakan I. Namun pada pelaksanaan tindakan II ini peneliti menggunakan strategi tanya jawab dengan jumlah kelompok yang lebih kecil agar mereka bisa mengungkapkan pendapatnya dengan lebih baik.

\section{c. Observasi}

Dengan melihat dari pelaksanaan tindakan I dan maka dalam tindakan II ini, diharapkan bisa memberi peningkatan yang signifikan terhadap efikasi diri siswa dalam mengetahui lebih bagaimana peningkatan Daya tarik belajar siswa selama proses belajar mengajar berlangsung dengan menggunakan metode jigsaw I.

Tabel di atas menunjukkan bahwa siswa yang sangat aktif 4 orang (20\%), siswa yang aktif 6 orang (30\%), siswa yang kurang aktif 7 orang (35\%), siswa yang tidak aktif 3 orang $(15 \%)$ dan siswa yang sangat tidak aktif 0 orang $(0 \%$

proses belajarnya. Peneliti dan guru melakukan pengamatan terhadap penerapan mtode jigsaw II dalam meningkatkan pemahaman siswa yang tujuannya adalah efikasi diri, Peneliti juga mengamati perubahan yang terjadi pada pertemuan II.

Tabel. 2.2 Frekuensi Tingkat Keaktifan SiswaSiklus II

\begin{tabular}{|l|l|l|l|}
\hline $\begin{array}{l}\text { Kateg } \\
\text { Ori }\end{array}$ & $\begin{array}{l}\text { Frekue } \\
\text { nsi }\end{array}$ & $\begin{array}{l}\text { Persent } \\
\text { ase } \\
\text { Frekue } \\
\text { nsi }\end{array}$ & $\begin{array}{l}\text { Tingka } \\
t \\
\text { Keakti } \\
\text { fan }\end{array}$ \\
\hline $\begin{array}{l}90 \%- \\
100 \%\end{array}$ & 5 & $25 \%$ & $\begin{array}{l}\text { Sangat } \\
\text { Aktif }\end{array}$ \\
\hline $75 \%$ & 11 & $55 \%$ & Aktif \\
\hline $89 \%$ & & & \\
\hline $55 \%-$ & 4 & $20 \%$ & Kuran \\
\hline
\end{tabular}

\begin{tabular}{|l|r|r|l|}
\hline $74 \%$ & & & $\begin{array}{l}\text { Aktif } \\
\text { Akt }\end{array}$ \\
\hline $35 \%-$ & 0 & $0 \%$ & Tidak \\
$54 \%$ & & & Aktif \\
\hline
\end{tabular}


Purnama Purba: Penggunaan Model-Model..

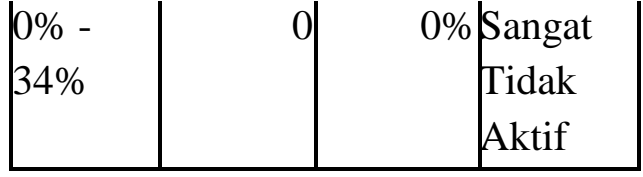

Dari tabel di atas, dapat diketahui bahwa tingkat Daya tarik belajar siswa berada pada kategori aktif. Hal itu dapat dilihat dari persentase tingkat keaktifan siswa yang sangat aktif dan aktif masingmasing adalah $25 \%$ dan $55 \%$. Hal ini berarti bahwa telah terjadi peningkatan yang positif dan signifikan dari keaktifan belajar siswa dari pertemuan sebelumnya, dimana tingkat keaktifan belajar siswa pada peretemuan I berada kategori kurang aktif.

\section{d. Refleksi}

Dari hasil observasi, dilakukan analisis pada tindakan pertemuan II kemudian dilanjutkan dengan refleksi. Pada peretemuan II, peniliti melihat bahwa telah terjadi peningkatan Daya tarik belajar siswa dari pertemuan sebelumnya.

\section{Pertemuan III}

Hasil penelitian Pertemuan II menyajikan laporan hasil-hasil setiap tahapan penelitian ini, mulai perencanan, pelaksanaan tindakan, observasi dan evaluasi, dan refleksi.

Tabel. 2.3

Frekuensi Tingkat Keaktifan Siswa Pertemuan III

\begin{tabular}{|c|c|c|c|}
\hline $\begin{array}{l}\text { Kateg } \\
\text { ori }\end{array}$ & $\begin{array}{l}\text { Frekue } \\
\text { Nsi }\end{array}$ & $\begin{array}{l}\text { Persent } \\
\text { ase } \\
\text { Frekue } \\
\text { nsi }\end{array}$ & $\begin{array}{l}\text { Tingka } \\
\text { T } \\
\text { Keakti } \\
\text { Fan }\end{array}$ \\
\hline $\begin{array}{l}90 \%- \\
100 \%\end{array}$ & 2 & $10 \%$ & $\begin{array}{l}\text { Sangat } \\
\text { Aktif }\end{array}$ \\
\hline $\begin{array}{l}75 \% \\
89 \%\end{array}$ & 5 & $25 \%$ & Aktif \\
\hline $\begin{array}{l}55 \%- \\
74 \%\end{array}$ & 5 & $25 \%$ & $\begin{array}{l}\text { Kuran } \\
\text { G } \\
\text { Aktif }\end{array}$ \\
\hline $\begin{array}{l}35 \%- \\
54 \%\end{array}$ & 5 & $25 \%$ & $\begin{array}{l}\text { Tidak } \\
\text { Aktif }\end{array}$ \\
\hline $\begin{array}{l}0 \%- \\
34 \%\end{array}$ & $\beta$ & $15 \%$ & \begin{tabular}{|l|} 
Sangat \\
Tidak \\
Aktif
\end{tabular} \\
\hline
\end{tabular}

Tabel di atas menunjukkan bahwa siswa yang sangat aktif 2 orang (10\%), siswa yang aktif 5 orang (25\%), siswa yang kurang aktif 5 orang $(25 \%)$, siswa yang tidak aktif 5 orang $(25 \%)$ dan siswa yang sangat tidak aktif 3 orang (15\%).

\section{SIMPULAN}

Berdasarkan analisis data dan hasil penelitian tindakan kelas (classroom Action research) yang dilakukan dapat disimpulkan bahwa:

1).Penggunaan model pembelajaran Jigsaw I dapat meningkatkan daya tarik belajar siswa Kelas IV 064012 Kec Medan Petisah. Terlihat dari tabel observasi yang sudah di lakukan dimana menunjukkan bahwa siswa yang sangat aktif 4 orang (20\%), 
siswa yang aktif 6 orang (30\%), siswa yang kurang aktif 7 orang (35\%), siswa yang tidak aktif 3 orang $(15 \%)$ dan siswa yang sangat tidak aktif 0 orang (0\%). 2).Penggunaan model Pembelajaran Jigsaw II dapat meningkatkan daya tarik belajar siswa Kelas IV 064012 Kec Medan Petisah bahkan lebih meningkat dibandingkan dengan Jigsaw I, dapat diketahui bahwa tingkat daya tarik belajar siswa berada pada kategori aktif. Hal itu dapat dilihat dari persentase tingkat keaktifan siswa yang sangat aktif dan aktif masing-masing adalah $25 \%$ dan $55 \%$.

\section{DAFTAR RUJUKAN}

Alkitab. 2013. Jakarta: Lembaga Alkitab Indonesia.

Arikunto Suharsimi. 2005. Prosedur Suatu Pendekatan Praktis. Jakarta: Bina Aksara.

Dimyanti \& Mudjiono. 2002. Belajar Dan Pembelajaran. Jakarta: Rineka Cipta.

Dimyati dan Mudjiono. 2009. Belajar dan Pembelajaran, Jakarta: Rineka Cipta.

Gultom, Ramli. 2010. Menjadi Penulis Penelitian Tindakan di kelas dan di sekolah, Medan: USU Perss.
Hariyanto. 2000. Perbandingan Hasil Belajar Matematika Antara Siswa Yang Pembelajarannya

Menggunakan Model Kooperatif Tipe Jigsaw Dengan Model Tradisional Di Kelas II Man Jember. Tesis Bandung: PPS UPI.

M Abdurrahman dan B Totok. 2000. Memahami dan Menangani Siswa dengan Problema dalam Relajar: Pedoman Guru. Jakarta: Proyek Peningkatan Mutu SLTP Direktorat Pendidikan Menengah Umum, Direktorat Pendidikan Dasar dan Menengah; Departemen Pendidikan Nasional.

Mukhtar H. 2007. Bimbingan Skripsi,Tesis, dan Artikel

Ilmiah: Panduan Berbasis Kualitatif Lapangan Dan Perpustakaan. Jakarta: Bandung, Jurnal Info Media.

Nainggolan. JM., 2008. Strategi Pendidikan Agama Kristen, Jakarta: Generasi Info Media. 
Purnama Purba: Penggunaan Model-Model.. 
ELEMENTARY SCHOOL JOURNAL VOLUME 9, NO. 1, JUNI 2019 